\title{
Brand Service Quality, Satisfaction, Trust and Preference as Predictors of Consumer Brand Loyalty in the Retailing Industry
}

Richard Chinomona

Donald Mahlangu

David Pooe

Department of Logistics, Vaal University of Technology Private Bag X021, Vanderbijlpark 1900, South Africa

E-mail: rchinos@hotmail.com

\section{Doi:10.5901/mjss.2013.v4n14p181}

\begin{abstract}
Notwithstanding the increasing acknowledgement of the prominence of brand loyalty in business performance, research efforts directed at investigating the influence brand service quality, satisfaction and trust on brand loyalty in the context of South African retailing industry have largely been neglected. Therefore, the principal objective of this study is to fill this void. In particular, the current study seeks to explore the direct effects of brand service quality on consumer brand satisfaction and brand trust; and the mediating role of brand satisfaction and trust in brand service quality - brand loyalty relationship. To empirically test the six posited research hypotheses, data was collected from consumers in Vanderbijlpark city of Gauteng Province in South Africa. The collected data was analyzed using Smart PLS statistical software for structural equation modeling. Managerial implications of the research findings are discussed and limitations and future research directions are indicated.
\end{abstract}

Keywords: Brand service quality, Brand commitment, Brand satisfaction, Brand trust, Brand preference, Brand loyalty

\section{Introduction}

The ever increasing competition among brands has led marketers to utilizing various means to maintain consumer brand loyalty (Keller, 2008; Kotler \& Keller, 2007). The importance of brand loyalty has been recognized in the marketing literature for at least three decades (Howard \& Sheth, 1969). Brand loyalty has often been used interchangeably with concepts such as repeat purchase, preference, commitment and allegiance (Azize, Cemal \& Hakan, 2011). Hence, loyal customers are loyal consumers of the brand and perform repeat purchases and recommend the brand to those around. According to Uncles, Dowling \& Hammond (2003) loyalty may be conceived in terms of favorable attitudes or beliefs towards a brand, manifested in an emotional attachment to the brand or it may be thought of purely in terms of behavior, the regular purchasing of a particular brand. Interesting to note too is the growing recognition that a brand's worth is intimately tied to consumer reactions to product(s) or service(s) related to a particular brand name.

As a result of the widely acclaimed importance of brand loyalty, much scholarly interest in the branding literature has centered on identifying the antecedents of brand loyalty in the retailing industry (Agustin \& Singh, 2005). Among others, brand preference is one of the recognized predictor of brand loyalty (Ballester \& Aleman, 2001). Research focused on brand preference have tried to investigate the reasons why consumers prefer certain brands over others (Yee et al., 2008). In the same vein, some researchers have identified brand satisfaction and brand trust as among the most important precursors of brand preference (Azar \& Fuller, 2008; Yee et al. 2010; ). While they is growing empirical evidence for instance, indicating that brand experience has a positive significant influence on brand satisfaction and trust, it is not clear in the marketing or branding literature in particular, the extent to which brand service quality influence brand loyalty via brand satisfaction and trust. Moreover, most of the previous studies on antecedents of brand loyalty have by and large been conducted in developed countries such as the USA and Europe and some parts of Asia. Indeed, there is a void that is warrant further academic scrutiny.

In view of this identified research gap, the objectives of this study are three-fold. First, the current study seek to investigate the influence of brand service quality on brand loyalty. Second, this study also intend to explore the mediating 
influence of brand satisfaction, trust and preference in the brand service quality - brand loyalty relationship. Finally, an attempt is made to apply the Theory of Reasoned Action (TRA) in the context of this study. The Theory of Reasoned Action is deemed to provide an appropriate theoretical grounding to this study. Over and above, since the current study is one of the few studies conducted in the African setting - a context that often most neglected by some researchers, it is expected to generate and add new literature to the existing spate of branding literature from an African perspective. Furthermore, the findings of this study are also expected to provide practical implications to branding managers.

The rest of the article is organized as follows. First, a review of the literature is undertaken then a conceptual framework and hypotheses development are provided. These are followed by the discussion of methodology, the constructs and scales used. The next section is a presentation of the analysis of results. Finally managerial implications, limitations and future research directions are provided.

\section{Literature Review}

\subsection{The Theory of Reasoned Action}

The Theory of Reasoned Action (TRA) can be traced back to Fishbein (1980). The theory was developed to explain how a consumer leads to a certain buying behavior (Fishbein, 1980). It asserts that attitude toward buying and subjective norm are the antecedents of performed behavior. Lutz (1991) offered two important propositions underlying the theory of reasoned action. First, to predict a purchase behavior, it is necessary to measure a person's attitude toward performing that behavior, not just the general attitude toward the object around which the purchasing behavior is. Second, in addition to the attitude toward the behavior, TRA includes a second determinant of subjective norm. The subject norm aspect of TRA is intended to measure the social influences on a person's behavior (i.e., family members' expectations). The theory of reasoned action has been used to explain consumer brand loyalty through the influence of formed consumer attitude $(\mathrm{Ha}, 1998)$. In the context of this study, the attitudes might be emanating from a positive evaluation of a brand service quality which intern lead to brand satisfaction, trust and preference.

\subsection{Brand Service Quality}

Brand service quality and the associated behavioral outcomes have received a good deal of attention in the literature (cf. Bolton \& Drew, 1994; Jensen \& Markland, 1996; Rauyruen, Kenneth \& Miller, 2006). For instance, some researchers have examined the influence of brand service quality on customer satisfaction (Heung, Wong, \& Qu, 2002; Clemes, 2011). The relationship between customer satisfaction and service quality has received a good deal of attention in the literature (cf. Parasuraman, 1988; Bolton \& Drew, 1994; Dabholkar, Shepherd \& Thorpe, 2000). Besides, a considerable number of authors have argued that brand service quality is an important determinant of brand loyalty although its exact relationship has remained unclear (Gremler and Brown, 1996; Harris and Goode, 2004). However, according to Tam (2000) brand service quality has a significant influence on brand trust. In this study brand service quality is defined as the quality of services offered by a certain brand which meets or exceeds the expectations of a certain customer (Heung, Wong, \& Qu, 2002)

\subsection{Brand Satisfaction}

Brand satisfaction is one of the branding concept that has been extensively researched in the marketing literature (e.g. Jones \& Suh, 2000; Pappu \& Quester, 2006; Kuenzel and Halliday, 2008; Tsai, 2011). Among some of the identified behavioural outcomes of brand satisfaction are brand attachment (Chinomona, 2013), brand trust (Ringham, Johnson, \& Spreng, 1994; Erikson \& Vaghut 2000; Bennett et al, 2005), brand preference (Bennett, 2001; Jones \& Suh, 2000) and brand loyalty (Pappu \& Quester, 2006). He, Li and Harris (2012) indicate that satisfaction occurs when the performance of a brand meets the expectations of the purchaser. Thus, if performance fails to meet expectations, negative disconfirmation occurs, which results in dissatisfaction (Patterson, Johnson \& Spreng, 1997). In this regard, Nam, Ekinci and Whyatt (2011) described brand satisfaction as an evaluative summary of direct consumption experience, based on the discrepancy between prior expectation and the actual performance perceived after consumption (Kuenzel \& Halliday, 2008). However, in the current study brand satisfaction is defined according to Chinomona (2013) who expressed it as the cumulative satisfaction as overall consumer's evaluation based on the consumer's total purchase and experience with a brand of product or service. 


\subsection{Brand Trust}

In the branding literature the concept of brand trust is based on the idea of a brand-consumer relationship, which is seen as a substitute for human contact between the company and its consumers (Zehir et al.2011). Brand trust is defined by Agustin and Singh (2005) as a consumer's confident beliefs that he or she can rely on the brand to deliver promised services or products. However, Chaudhuri and Holbrook (2001) defined brand trust as the willingness of the average consumer to rely on the ability of the brand to perform its stated functions. (Chaudhuri \& Holbrook, 2001). Some of the behavioral outcomes of brand trust identified in the extant literature include brand preference, brand attachment and brand loyalty (Reichheld et al., 2000; Sirdeshmukh et al., 2002; Verhoef et al., 2002; Chiou \& Droge, 2006; Kim, Byoungho , Jane \& Swinney 2008; Chinomona, 2013).

\subsection{Brand Preference}

According to Aakar (1991) and Keller (1993), brand preference is a set of brand assets and liabilities linked to a brand and a customer's subjective and intangible assessment of the brand, above and beyond its objectively perceived value. Much of the literature on brand preference has focused on antecedents of brand preference (Bart et al.2005). Among some of the identified precursors to brand preference are positive brand experience, brand trust and brand satisfaction (De Asis 2001; Chinomona, 2013). However, some researchers have focused on the consequences of brand preferences. For example, Shankar, Azar, and Fuller (2008) found that consumers' preference towards a brand contribute to the brand's relative strength in a market, which drives a brand's value in the marketplace. In this study brand preference is defined according to Aakar (1991) and Keller (1993) definition aforementioned.

\subsection{Brand Loyalty}

They appear to numerous definition for brand loyalty in the marketing literature. For instance, Giddens (2002) assert that brand loyalty exist when a consumer is willing to pay a high price for a certain brand within the same product group and recommends that brand to the people around them. Brand loyalty is also expressed as a deeply held commitment to rebuy or patronize a preferred product/ service consistently in the future, thereby causing repetitive brand purchase (Oliver, 1999; Knox \& Walker, 2001; Rundle-Thiele \& Mackay, 2001). It is argued in the extant literature that brand loyalty results in sales revenues, market share, profitability to the firms, and help them grow or at least maintain themselves in the marketplace (Keller, 2008; Aaker, 1991, Kapferer, 1997). In addition to that, brand loyalty is a prerequisite for a firm's competitiveness and profitability (Chaudhuri \& Holbrook, 2001). For this reason, every firm desires high brand loyalty associated with its brands (Morrison \& Crane, 2007).

\section{Conceptual Model and Hypothesis Development}

Based on the reviewed branding literatures, a conceptual model (Figure 1) is developed. In this conceptualized model brand service quality is the predictor variable, while brand satisfaction, brand trust and brand preference are the mediating variables. Brand loyalty is the outcome variable. The proposed conceptual linkages of these constructs are as follows: brand service quality provides the starting point of the model and directly affects brand trust and brand satisfaction. In turn, brand trust and brand satisfaction affect brand preference which eventually is expected to affect brand loyalty.

Figure 1: Conceptual research model

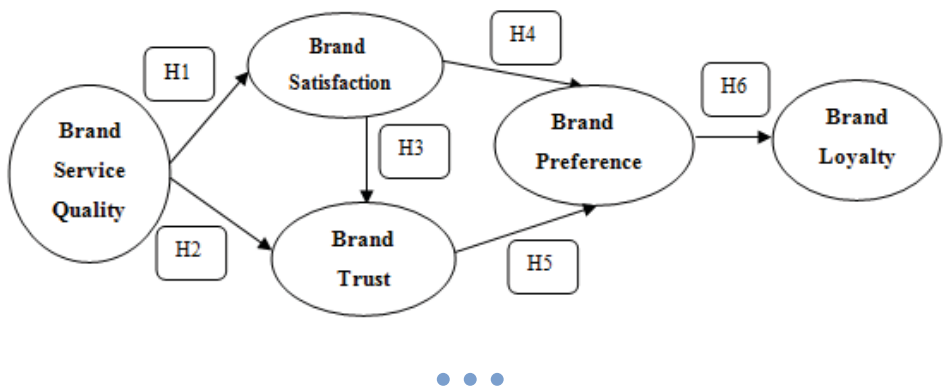




\subsection{Brand Service Quality, Brand Satisfaction and Trust}

Numerous researchers provide conceptual and empirical evidence to support a positive relationship between service quality and customer satisfaction. For instance, Oliver (1993) found that service quality is an antecedent of consumer satisfaction and is positively associated to customer satisfaction. Subsequent studies after Oliver (1993), also authenticated this finding. These studies among others include those by Dabholkar, Shepherd and Thorpe (2000), Heung, Wong, and Qu, (2002) and Tam (2000), who all confirmed a positive relationship between service quality and consumer satisfaction in the restaurant industry. In the same vein, Sultan and Mooraj (2001), Chen et al., (2002) and Harris and Goode (2004) among others, found a positive linkage between a number of service quality factors and trust. Drawing from the Theory of Reasoned Action (TRA) the current study submit that based on the perceived brand service quality attributes, consumers develop positive attitudes towards certain brands which eventually leads to their brand satisfaction and trust. Therefore, premised on the empirical evidence and the TRA, the current study hypothesizes that:

H1: Perceived product service quality is positively related to consumer perceived brand satisfaction.

H2: Perceived product service quality is positively related to consumer perceived brand trust.

\subsection{Brand Satisfaction and Brand Trust}

Trust in the purchased brand may be viewed as leverage of the satisfied consumers, which in return may reinforce the consumers' repeat buying behavior (Agustin \& Singh, 2005; Sahin et al., 2011). Since brand satisfaction is in other words an indication that consumers are convinced that the quality of service provided by brands meet or exceed their expectations, the current study submits that, this is likely to lead to brand trust in the long term (Harris \& Goode, 2004). This reasoning has been supported by prior studies in the empirical branding literature (Agustin \& Singh, 2005; Sahin et al. 2011). Thus, the higher the degree of positive brand satisfaction the customer realizes, the more they tend to trust that brand. Based on the previous empirical evidence, this study therefore hypothesizes that:

H3: Perceived brand satisfaction is positively related to consumer perceived brand trust.

\subsection{Brand Satisfaction, Brand Trust and Brand Preference}

Customers choose brands by comparing the level of satisfaction they get from among the different brands (Shankar, Azar, \& Fuller, 2008; Chiou \& Droge, 2006; Chinomona, 2013). However, those who are not satisfied with the offerings of the brand in terms of products and services quality will likely find alternatives while those who are satisfied will tend to stick to the brand as a preferred choice (Chen et al., 2002). It also reported in the branding literature that when customers develop trust in a particular brand, repurchasing is likely to occur, leading to brand preference (Sheth \& Parvatiyar, 1995; Zehir et al., 2011). Hence drawing from the empirical evidence from the branding literature, the current study hypothesizes that:

H4: Perceived brand satisfaction is positively related to consumer perceived brand preference.

H5: Perceived brand trust is positively related to consumer perceived brand preference.

\subsection{Brand Preference and Brand loyalty}

Consumers are willing to improve and sustain an affective bond with the brand that makes them feel warm and enjoyable (Chen \& Chang, 2008). At the same time, consumers with high brand preference would have stronger affective attachment for the brand (Keh et al., 2007). This entails that when there is a strong bond between a customer and a brand there is loyalty (Keller, 2008). Previous studies have supported a positive relationship between brand preference and brand loyalty (Chaudhuri \& Holbrook, 2001; Keller, 2008; Morrison \& Crane, 2007). Based on such reasoning, this paper hypothesizes that:

H6: Perceived brand preference is positively related to consumer perceived brand loyalty.

\section{Research Methodology}

\subsection{Sample and data collection}

The target population for the study was South African consumers in Gauteng. The sampling unit was the individual 
consumer. A mall intercept survey was used. This method has the advantage of speed, being less costly and that the researcher has control over respondent type. Four shopping malls in the Vaal region were selected for this survey. Students from the Vaal University of Technology were recruited as research assistants to distribute and collect the questionnaires. Of the total of 170 questionnaires distributed, 151 usable questionnaires were retrieved for the final data analysis, representing a response rate of 89 per cent. To eliminate differences in response patterns due to different reference points, all respondents were prompted to answer the questionnaire with reference to non-durable consumer goods. The reason for selecting this category was that consumers frequently purchase these products. In this regard, the respondents were asked to identify a product category in which they had frequently made a purchase intention decision. Respondents were then asked to name a brand in that category and were requested to think about that brand as they complete the entire questionnaire, guided by the research assistants.

\subsection{Measurement Instrument and Questionnaire Design}

Research scales were operationalized on the basis of previous work. Proper modifications were made in order to fit the current research context and purpose. Brand service quality was measured using five-items adapted from Brandy and Cronin (2001), while, brand satisfaction used eight-item measures adapted from (Salinas \& Perez, 2009). Brand trust measures were adopted from (He, Li \& Harris, 2012) and brand preference measures were adopted from (Chen \& Chang, 2007). On the other hand, brand loyalty used a four-item measure adopted from (Chaudhuri \& Holbrook, 2001). All the measurement items were measured on a five-point Likert-type scale that was anchored by $1=$ strongly disagree to $5=$ strongly agree to express the degree of agreement.

\subsection{Respondent Profile}

Table 1 presents the description of the participants. The respondents were asked to report their demographic information on gender, age, marital status and education. The respondents were predominantly females (57.6\%). The median age group of the respondents was that of less than 30 years (54.3\%). 57\% of the respondents were single. About $71 \%$ of the respondents had either high school (43.7\%) or university level of education $(27.2 \%)$ and the remainder had primary school (19.9) or postgraduate level of education (0.09\%).

Table 1: Sample Demographic Characteristics

\begin{tabular}{|c|c|c|}
\hline Gender & Frequency & Percentage \\
\hline Male & 64 & $42.4 \%$ \\
\hline Female & 87 & $57.6 \%$ \\
\hline Total & 151 & $100 \%$ \\
\hline & & \\
\hline Age & Frequency & Percentage \\
\hline$\leqq 30$ & 82 & $54.3 \%$ \\
\hline $31-60$ & 51 & $33.8 \%$ \\
\hline$\geqq 60$ & 18 & $11.9 \%$ \\
\hline Total & 151 & $100 \%$ \\
\hline
\end{tabular}

\section{Data Analysis}

In this study, structural equation modeling (SEM) approach using Smart (PLS) statistical software was used to test the posited hypotheses in the conceptual research model (Ringle, Wende \& Will, 2005). According to Liljander, Polsa and van Riel (2009), PLS is a prediction-oriented, variance-based approach to SEM, premised on very few assumptions about the distribution of the variables. Furthermore, Smart PLS requires relatively few observations, unlike the more traditional Maximum Likelihood (ML) SEM techniques such as LISREL (Joreskog \& Sorbom, 1989) and AMOS (Byrne, 2001). Since the current study sample size is relatively small (151) Smart PLS was found more appropriate and befitting the purpose of the current study.

\subsection{Measurement model}

Reliability was mainly checked using Composite Reliability (CR) and Cronbach's alpha value. To ensure convergent 
validity, items loaded on their respective (a priori) constructs were checked if their loadings were greater than 0.5 , while discriminant validity was checked by Average Variance Extracted (AVE) value and ensuring that there was no significant inter-research variables cross-loadings (Chin, 1998). In this paper, Smart PLS performed a Confirmatory Factor Analysis (CFA) while estimating the structural equation model (SEM). The CFA results are reported in Table 2 and Figure 2, while the SEM results are presented in Table 4 and Figure 2.

Table 2: Accuracy Analysis Statistics

\begin{tabular}{|c|c|c|c|c|c|c|c|c|}
\hline \multicolumn{2}{|c|}{$\begin{array}{l}\text { Research } \\
\text { Construct }\end{array}$} & LV Index Value & R-Squared Value & Cronbach's $\alpha$ value & C.R. Value & AVE Value & Communality & $\begin{array}{l}\text { Factor } \\
\text { Loading }\end{array}$ \\
\hline \multirow{5}{*}{ SQ } & SQ 1 & \multirow{5}{*}{4.322} & \multirow{5}{*}{0.000} & \multirow{5}{*}{0.899} & \multirow{5}{*}{0.919} & \multirow{5}{*}{0.697} & \multirow{5}{*}{0.6965} & 0.726 \\
\hline & SQ 2 & & & & & & & 0.859 \\
\hline & SQ 3 & & & & & & & 0.886 \\
\hline & SQ 4 & & & & & & & 0.785 \\
\hline & SQ 5 & & & & & & & 0.904 \\
\hline \multirow{8}{*}{ BS } & BS 1 & \multirow{8}{*}{4.411} & \multirow{8}{*}{0.4709} & \multirow{8}{*}{0.890} & \multirow{8}{*}{0.912} & \multirow{8}{*}{0.567} & \multirow{8}{*}{0.5666} & 0.678 \\
\hline & BS 2 & & & & & & & 0.684 \\
\hline & BS 3 & & & & & & & 0.767 \\
\hline & BS 4 & & & & & & & 0.787 \\
\hline & BS 5 & & & & & & & 0.776 \\
\hline & BS 6 & & & & & & & 0.783 \\
\hline & BS 7 & & & & & & & 0.814 \\
\hline & BS 8 & & & & & & & 0.720 \\
\hline \multirow{4}{*}{ BT } & BT 1 & \multirow{4}{*}{4.033} & \multirow{4}{*}{0.351} & \multirow{4}{*}{0.774} & \multirow{4}{*}{0.854} & \multirow{4}{*}{0.594} & \multirow{4}{*}{0.594} & 0.739 \\
\hline & BT2 & & & & & & & 0.730 \\
\hline & BT 3 & & & & & & & 0.850 \\
\hline & BT 4 & & & & & & & 0.757 \\
\hline \multirow{4}{*}{ BP } & BP 1 & \multirow{4}{*}{4.456} & \multirow{4}{*}{0.514} & \multirow{4}{*}{0.887} & \multirow{4}{*}{0.922} & \multirow{4}{*}{0.748} & \multirow{4}{*}{0.748} & 0.850 \\
\hline & BP 2 & & & & & & & 0.843 \\
\hline & BP 3 & & & & & & & 0.877 \\
\hline & BP 4 & & & & & & & 0.888 \\
\hline \multirow{4}{*}{$B L$} & BL 1 & \multirow{4}{*}{4.028} & \multirow{4}{*}{0.369} & & & & & 0.871 \\
\hline & $\mathrm{BL} 2$ & & & & & & & 0.813 \\
\hline & $\mathrm{BL} 3$ & & & 0.842 & 0.895 & 0.080 & 0.680 & 0.834 \\
\hline & $\mathrm{BL} 4$ & & & & & & & 0.839 \\
\hline
\end{tabular}

Note: $\mathrm{BSQ}=$ Brand service quality; BS = Brand satisfaction; $\mathrm{BT}=$ Brand Trust; $\mathrm{BP}=\mathrm{Brand}$ Preference, $\mathrm{BL}=$ Brand Loyalty, $\mathrm{C} . \mathrm{R}$.: Composite Reliability; AVE: Average Variance Reliability, ${ }^{*}$ Scores: 1 - Strongly; Disagree; Disagree; 3 - Neutral; 5 - Strongly Agree

As can be seen (Table 2), the majority of items have loadings greater than 0.5 (Nunnally \& Bernstein, 1994), indicating that they explain at least $50 \%$ of what they expected to measure (convergent validity). The lowest AVE value is 0.567 which exceeds the recommended 0.5 (Fornell \& Larcker, 1981) and is an indication of the existence of discriminant validity. However, to guarantee sufficient discriminant validity between the research constructs, the square root of the Average Variance Extracted (AVE) of each factor should exceed the correlations between that factor and all other factors (Fornell \& Larcker, 1981). In this study the least squared root of AVE is 0.567 . This thus, further confirms the existence of discriminant validity. Using the composite reliability value and cronbach's alpha value, the measurement instruments reliability was assessed and lowest values are 0,854 and 0.774 respectively, which exceeds the recommended acceptable value of 0.7 (Nunnally \& Bernstein, 1994). All in all, these results confirm the reliability and validity of the measurement used in this study.

Table 3: Inter-Construct Correlation Matrix

\begin{tabular}{|l|l|l|l|l|l|}
\hline \hline Research Constructs & BSQ & BS & BT & BP & BL \\
\hline Brand Service Quality (BSQ) & 1.000 & & & & \\
\hline
\end{tabular}




\begin{tabular}{|l|l|l|l|l|l|}
\hline Brand Satisfaction (BS) & 0.542 & 1.000 & & & \\
\hline Brand Trust (BT) & 0.390 & 0.610 & 1.000 & & \\
\hline Brand Preference (BP) & 0.622 & 0.465 & 0.553 & 1.000 & \\
\hline Brand Loyalty (BL) & 0.417 & 0.625 & 0.674 & 0.511 & 1.000 \\
\hline
\end{tabular}

Note: $\mathrm{BS}=$ Brand Service quality; BS = Satisfaction; BT = Brand Trust; BP=Brand Preference BL = Brand Loyalty

Smart PLS software does not provide goodness-of-fit measures for the full path model unlike LISREL and AMOS, but it provides only $\mathrm{R}^{2}$ values for the dependent variables. However, a method to calculate a global goodness-of-fit (GoF) measure was proposed by Amato, Vinzi and Tenenhaus (2004), and this method takes into account both the quality of the measurement model and the structural model (Tenenhaus, Vinzi, Chatelin \& Lauro, 2005; Streukens, 2008).

\subsection{Testing of the hypotheses}

The results in Table 4 and Figure 2 provide support for all the six (6) hypotheses. All the six hypotheses were posited to be positive and significant. $\mathrm{H} 1$ posited a positive relationship between brand service quality and brand satisfaction, while $\mathrm{H} 2$ hypothesised a positive association between brand service quality and brand trust. $\mathrm{H} 3$ had posited a positive relationship between brand satisfaction and brand trust, while $\mathrm{H} 4$ hypothesised a positive relationship between brand satisfaction and brand preference. H5 hypothesised a positive relationship between brand trust and brand preference while $\mathrm{H} 6$ posited a positive relationship between brand preference and consumer brand loyalty.

The hypotheses testing results obtained using Smart PLS analysis are shown in Figure 2 and Table 4. Standardized path coefficients are expected to be at least 0.2 and preferably greater than 0.3 (Chin, 1998). The reliability of each coefficient is assessed from bootstrapping (300 resamples). Support is provided for four hypotheses $(\mathrm{H} 1, \mathrm{H} 3, \mathrm{H} 4$ and $\mathrm{H} 6$ ) with path coefficients $(0.686,0.461,0.598$ and 0.608 respectively) above 0.2 and significant (pb0.001) as shown in Figure 2 and Table 4. However, $\mathrm{H} 2$ and $\mathrm{H} 5$ although positive as hypothesized the relationships are insignificant $(0.184$, 0.179) which falls the requisite rule of thumb of above 0.2. The T-statistic value are indicated in Figure 2 and Table 4.

Figure 2: Measurement and Structural Model Results

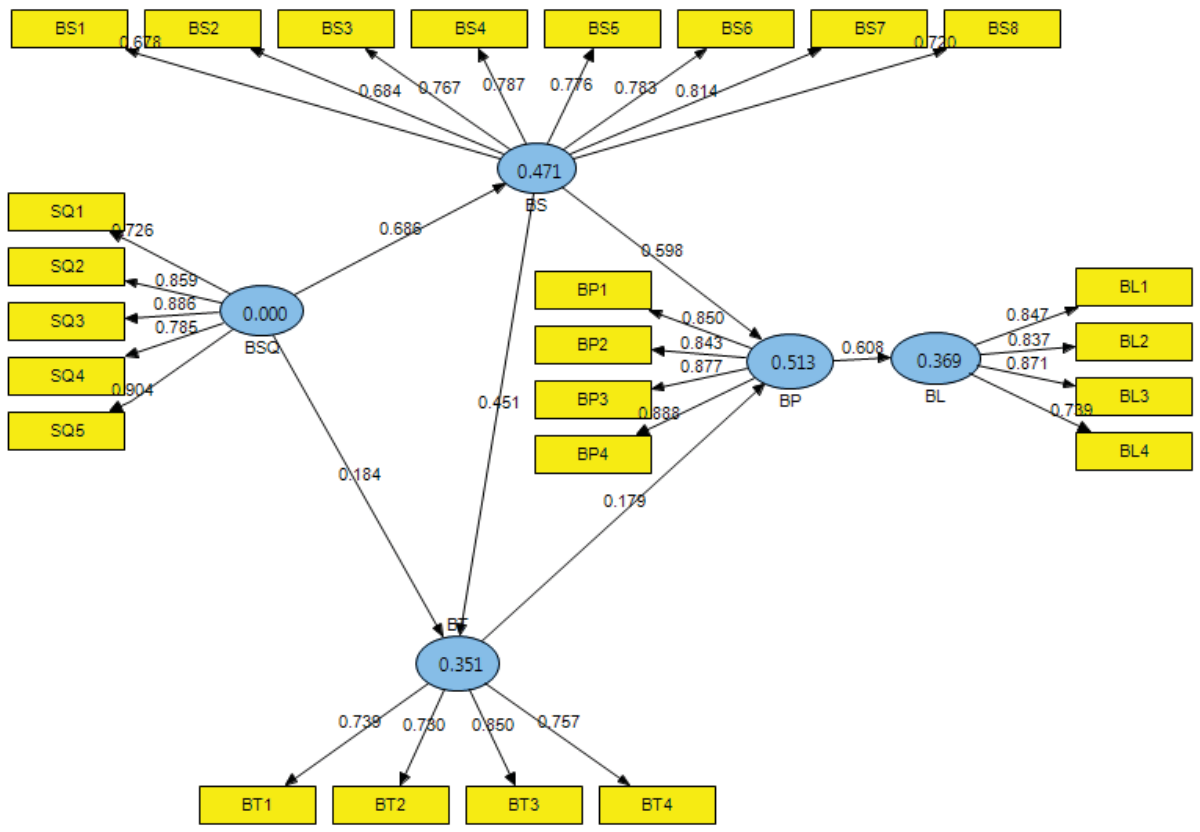

Note: BSQ = Brand Service quality; BS = Brand satisfaction; BT = Brand Trust; BP= Brand Preference, BL = Brand Loyalty 
Table 4: Results of Structural Equation Model Analysis

\begin{tabular}{|l|c|c|c|c|}
\hline \hline \multicolumn{1}{|c|}{ Proposed Hypothesis Relationship } & Hypothesis & Path Coefficients & T-Statistics & Rejected / Supported \\
\hline Brand Service Quality (BSQ) $\rightarrow$ Brand satisfaction (BS) & H1 & 0.686 & 2.688 & Supported \\
Brand service Quality (BSQ) $\rightarrow$ Brand Trust (BT) & H2 & 0.184 & 1.425 & Not Supported \\
Brand Satisfaction (BS) $\rightarrow$ Brand Trust (BT) & H3 & 0.451 & 13.551 & Supported \\
Brand Satisfaction (BS) $\rightarrow$ Brand Preference (BP) & H4 & 0.598 & 7.092 & Supported \\
Brand Trust (BT) $\rightarrow$ Brand Preference (BP) & H5 & 0.179 & 1.290 & Not Supported \\
Brand preference(BP) $\rightarrow$ Brand Loyalty (BL) & H6 & 0.608 & 10.581 & Supported \\
\hline \hline
\end{tabular}

Note:BSQ = Brand Service quality; BS = Brand Satisfaction; BP= Brand Preference; BT = Brand Trust; BL = Brand Loyalty

\section{Conclusion and Discussion}

The objectives of this study were to explore the influence of brand service quality on brand satisfaction, brand trust, brand preference and consequently brand loyalty. In particular, six hypotheses were postulated. To test the proposed hypotheses, data were collected from Gauteng Province in South Africa. The empirical results supported all the posited research hypotheses $(\mathrm{H} 1, \mathrm{H} 3, \mathrm{H} 4$ and $\mathrm{H} 6)$ in a significant way except for $\mathrm{H} 2$ and $\mathrm{H} 5$. This means that the findings on $\mathrm{H} 2$ and $\mathrm{H} 5$ are inconsistent with the evidence from the previous studies (Yoon, 2002; Berry, 2000; Sultan and Mooray, 2001; Yee et al., 2008; 2011; Chaudhuri \& Holbrook, 2001; Chiou \& Droge, 2006; Aaker, 2004)

The results indicate that brand service quality has a stronger effect on brand satisfaction $(0.686)$ than it has on brand trust (0.184). The relationship between brand satisfaction and brand trust is significantly strong (0.451). This finding indicates that brand service quality has significant influence on brand trust via brand satisfaction. In other words, this means that consumers will not trust the service quality of a brand unless they are first satisfied with that brand's service quality. Also important to note is the fact that brand satisfaction has a stronger effect on brand preference (0.598) when compared to brand trust effects on brand preference (0.179). However, the relationship between brand preference and brand loyalty is robust $(0.608)$

\subsection{Implications of the study}

The business world is ever-increasingly becoming competitive and sustaining brand loyalty is an enormous challenge for marketers. Many marketing researchers as well as practitioners emphasize the critical role of brand communication in order to affect brand image, brand trust and eventually brand loyalty. The current study was an attempt to investigate these relationships in an often most neglected context - the South African context. By and large, the findings of this empirical study are expected to have to provide fruitful implications to both practitioners and academicians.

On the practitioners' side, the important influence of brand service quality and mediating role of brand satisfaction in particular and brand trust to a lesser extent plays an important role in influence brand preference which eventually positively impact on brand loyalty in a significant way in South Africa is highlighted. This study therefore submits that marketers can benefit from the implications of these findings. For instance, by increasing the perceived level of brand preference through brand which in turn influences brand satisfaction, marketers will be able gain customer brand loyalty. In this case brand managers ought to improve brand service quality attributes that will impact on consumer satisfaction with their brands in order to ensure consumers prefer their brands and eventually remain loyal to their brands.

On the academic side, this study makes a significant contribution to the brand management literature by systematically exploring the impact of brand service quality on brand satisfaction, brand trust, brand preference and brand loyalty in South Africa. Overall, the current study findings provide tentative support to the proposition that brand service quality, brand satisfaction and brand trust and brand preference and that they should be recognized as significant antecedents for gaining and sustaining brand loyalty in South Africa.

\subsection{Limitations and Future Research}

Although this study makes significant contributions to both academia and practice, the research has its limitations. First and most significantly, the study can be strengthened by increasing the sample size and including participants in other geographical areas. Second, the current study was limited to South Africa in the Gauteng province. For results comparisons, subsequent researches should contemplate replicating this study in other provinces. Finally, the present study did not examine such factors as brand involvement, brand commitment, brand experience and brand image. Future 
studies should focus on these antecedents and their potential effects on brand loyalty.

\section{References}

Anderson C. J. \& Narus A. J. 1990. A Model of Distributor Firm and Manufacturer Firm Working Partnerships, Journal of Marketing, 54, $42-58$.

Agustin C., \& Singh J. 2005. Curvilinear Effects of Consumer Loyalty Determinants in Relational Exchanges, Journal of Marketing Research, XIII.

Aaker, David A. 1991. Managing Brand Equity: Capitalizing on the Value of a Brand Name. New York: The Free.

Aaker, D. 2004. Building a brand: The Saturn story. California Management Review, 114-133

Azize ,Ahin, Cemal Zehir, Hakan Kitap, 2011. 7th International Strategic Management Conference.

Bart Yakov, Shankar Andnkatesh, Sultan Fateena \& Urban Glen L. 2005. Are the Driandrs and Role of Online Trust the Same for All Web Sites and Consumers? A Large-Scale Exploratory Empirical Study, Journal of Marketing, 69, p.133-152.

Bagozzi, R. P., Gopinath, M., \& Nyer, P. U. 1999. The role of emotions in marketing. Journal of the Academy of Marketing Science, 27, 184-206

Bennett R, Hartel Cej, \& Mccoll-Kennedy Jr. 2005. Experience as a moderator of involvement and satisfaction on brand loyalty in a business-to-business setting. Industrial Marketing Management. 34 (1):97.

Bloemer JM \& Kasper, H.D.P. 1995. The complex relationship between consumer satisfaction and brand loyalty. Journal of Economics and Psychology 1995; 16 (2):311-29.

Bolton, R., 1998. A dynamic model of the duration of the customer's relationship with a continuous service provider: the role of satisfaction. Marketing Science 17 (1), 45-65.

Caruana, A. 2002. Service loyalty: The effects of service quality and the mediating role of customer satisfaction. European Journal of Marketing, 37(7-8), 811-828.

Chaudhuri, A., \& Holbrook, M.B. 2001. The chain of effects from brand trust and brand affect to brand performance: The role of brand loyalty. Journal of Marketing, 65(2), 81-93.

Chin, W. W. 1988. The partial lease squares approach for structural equation modeling. In G. A. Marcoulides (Ed.), Modern methods for business research (pp.295-336).

Chiou, J.-S., \& Droge, C. 2006. Service quality, trust, specific asset investment, and expertise: Direct and indirect effects in a satisfaction-loyalty framework. Journal of the Academy of Marketing Science, 34(4), 613-627.

Ching Fu Chen, Yu-Ying Chang. 2008 Airline brand equity, brand preference, and purchase intentions; The moderating effects of switching costs Journal of Air Transport Management 14, 40-42.

Dabholkar, P., Shepherd, C., \& Thorpe, D. 2000. A comprehensive framework for service quality: An investigation of critical conceptual and measurement issues through a longitudinal study. Journal of Retailing, 76(2), 139-173.

Eriksson K, \& Vaghult LA. 2000. Customer retention, purchasing behavior andl relationship substance in professional services. Industrial Marketing Management, 29, 363-372

Foa, U.G., \& Foa, E.B. 1974. Societal Structures of the Mind. Charles C. Thomas Publishers, Springfield, IL.

Fornell, C. \& Larcker D.F. 1981. Evaluating structural equation models with unobservable variables and measurement error. Journal of Marketing Research, 18(1):39-50.

Ganesh, J., Arnold, M.J., \& Reynolds, K.E. 2000. Understanding the customer base of service providers: an examination of the differences between switchers and stayers. Journal of Marketing 64,65

Giddens, N. 2002. Brand Loyalty and Decision Maker, lowa State University Extensions, 5 (54), 1-2.

Henning-Thurau, T., \& Klee, A, (1997). The impact of customer satisfaction and relationship quality on customer retention: a critical reassessment and model development. Psychology and Marketing 14 (8), 737-764.

Janda S, \& Ybarra A. 2006. Do product and consumer characteristics affect the relationship between online experience and customer satisfaction? Journal of Internet Commerce, 4(4): 133-51.,

Jones, M. A., \& Suh, J. 2000.Transaction-specific satisfaction and overall satisfaction: An empirical analysis. Journal of Services Marketing, 14(2), 147-159.27(2), 184-206.

Kotler, P., \& Armstrong, G. 2004. Principles of marketing. (10 thed), Upper Saddle River, Pearson

Kapferer, J. N. 1997. Strategic brand management: Creating and sustaining brand equity long term. London: Kogan Page Limite

Keller, K., \& Lehmann, D. 2006. Brands and branding: research findings and future priorities. Marketing Science, 25 (6): 740-59

Keller, K. L. 2008. Strategic Brand Management: Building, Measuring and Managing Brand Equity. Third Edition. New Jersey:Pearson Prentice Hall

Kotler, P, \& Keller, K. L. 2007. A Framework For Marketing Management. (3rd ed.). Upper Saddle River, NJ: Pearson/Prentice Hall

Keh, H.T., Nguyen, T.T.M., \& Ng, H.P. (2007).The effects of entrepreneurial orientation and marketing information on the performance of SMEs. Journal of Business Venturing, 22, $592-611$

Knox, S., \& Walker, D. 2001. Measuring and managing brand loyalty. Journal of Strategic Marketing, 9 (2):111-28

Morais, D., Kerstetter, D., \& Yarnal, C. 2006. The love triangle: loyal relationships among providers, customers, and their friends. Journal of Travel Research 44 (4), 379-38. 
Morris, MH, \& Holman, JL. 1998. Source loyalty in organisational markets: a dyadic perspective. Journal Business Research, 16 (2):117-31.

Morrison, S \& Crane, G. F. 2007. Building the Service Brand by Creating and Managing an Emotional Brand Experience, Journal of Brand Management, 14, 410-421.

Morais, D., Dorsch, M., \& Backman, S. 2005. Building loyal relationships between customers and providers: a focus on resource investments. Journal of Travel and Tourism Marketing 18 (1), 4957.

Nunnally, J. C., \& Bernstein, I. H. 1994. Psychometric theory. 3rd ed. Sydney, Australia McGraw Hill.

Oliver, R.L. 1999. Whence Consumer Loyalty?" Journal of Marketing, 63, 3-44

Parasuraman, A., Zeithaml, V.A., \& Berry, L.L. 1988. Servqual: a multiple-item scale for measuring customer perception of service quality. Journal of Retailing 64 (1), 12-40.

Sahin, A., Zehir, C., \& Kitapçi, H. 2011.The Effects Of Brand Experiences, Trust And Satisfaction On Building Brand Loyalty; An Empricial Research On Global Brands , The $7^{\text {th }}$ International Strategic Management Conference, Paris-France

Streukens, S. 2008. On the use of partial least squares path modeling in organizational research: an overview and illustration of its possibilities. Working Paper, Hasselt University, Hasselt.

Uncles, M., Ehrenberg, A., \& Hammond, K. 1995. Patterns of buyer behavior: Regularities, models and extensions. Marketing Science 14 (3), G71-G78, Part 2 of 2.

Wetzels, M., Odekerken-Schröder, G., \& Van Oppen, C. 2009. Using PLS path modeling for assessing hierarchical construct models: guidelines and empirical illustration. Management Information Systems Quarterly, 33(1), 177-195.

Yee, R.W.Y., Yeung, A.C.L., Cheng, T.C.E. (2008).Theimpactofemployeesatisfaction on quality and profitability in high-contact service industries. Journal of Operations Management. 26(5), 651-668.

\section{Appendix: Measurement Instruments}

\section{Brand Service Quality}

This brand provides superior service

This brand offers excellent service

I have always excellent experience when I use this brand

I feel good about what this brand offers to its customers

Overall, I would say the quality of service of this brand is excellent

\section{Brand Satisfaction}

I am very satisfied with the service provided by this brand

I am very satisfied with this brand.

I am very happy with this brand.

This brand does a good job of satisfying my needs.

The service-products provided by this brand is very satisfactory

I believe that using this brand is usually a very satisfying experience

I made the right decision when I decided to use this brand.

I am addicted to this brand in some way

\section{Brand Trust}

I trust this brand

I rely on this brand

This is an honest brand

This brand is safe

\section{Brand Preference}

I feel that this brand is appealing to me

I prefer this brand to other brand of its type

If I was to buy any product, I would prefer this brand if everything else was equal

In total I prefer this brand

\section{Brand Loyalty}

The next time I need that product, I will buy the same brand

I intend to keep purchasing this brand.

I am committed to this brand

I would be willing to pay a higher price for this brand over other brands. 